\title{
PENGARUH MOTIVASI DAN PERSEPSI TERHADAP MINAT MAHASISWA MENGIKUTI PENDIDIKAN PROFESI AKUNTANSI (PPAK) DI KOTA SEMARANG
}

\author{
Hesti Fajarsari \\ Akademi Entrepreneurship Terang Bangsa
}

\begin{abstract}
This study investigates the effect of motivation (quality, career, economic and social) and perception (the cost of education and study duration) on students' interest in taking PPAk. The variables used are quality motivation, career motivation, economic motivation, social motivation, perception of education costs and perception of study duration as independent variables, and student interest in accepting PPAk as the dependent variable. The study used a questionnaire with a total sample of 73 people. The analysis tool uses multiple linear regression.

The results showed that quality motivation, career motivation, economic motivation, social motivation, perception of educational costs and perception of study duration simultaneously had a significant effect on the interest of accounting students following the PPAk. The value of the regression model obtained by 0.356, which means that $35.6 \%$ of students' interest in participating in PPAk can be explained by the 6 variables. However, based on a partial analysis, only career motivation and social motivation have a significant positive effect on the interest of accounting students of PPA studies in the city of Semarang. While other variables such as quality motivation, economic motivation, perceptions of educational costs and perception of study duration did not affect the interest of accounting students in taking PPAk in the city of Semarang.
\end{abstract}

Keywords: motivation, perception, and students' interest in taking PPAk 


\section{PENDAHULUAN}

Pendidikan Profesi Akuntansi (PPAk) merupakan jenjang pendidikan tambahan yang ditujukan bagi seorang lulusan sarjana ekonomi jurusan akuntansi yang ingin mendapatkan gelar Akuntan. Surat Keputusan (SK) Mendiknas No. 179/U/2001 menyatakan bahwa lulusan sarjana strata satu (S1) jurusan akuntansi berkesempatan menempuh pendidikan profesi akuntansi di Perguruan Tinggi yang telah ditunjuk oleh Direktorat Jenderal Pendidikan Tinggi. Mereka yang telah menempuh Pendidikan Profesi Akuntansi nantinya akan berhak memperoleh sebutan profesi Akuntan (Ak), dan juga semakin berpeluang meniti karir sebagai auditor pemerintahan, auditor internal, akuntan sektor publik, akuntan manajemen, akuntan pendidik, akuntan perpajakan, akuntan keuangan, maupun akuntan sistem informasi.

Program pendidikan profesi akuntan merupakan jenis pendidikan tinggi setelah program sarjana atau setara yang menyiapkan mahasiswa dalam pekerjaan yang memerlukan persyaratan keahlian khusus di bidang akuntansi (PerMenKeu, 2014). Pendidikan profesi akuntansi mencakup perkuliahan dan Ujian Sertifikasi Akuntan Profesional (Lulusan pendidikan profesi akuntansi dahulu berhak menyandang gelar akuntan yang disingkat dengan "Ak" (MenDikNas, 2001). Namun, saat ini untuk mendapatkan gelar akuntan atau sekarang disingkat dengan "Ak", harus terlebih dahulu lulus ujian sertifikasi akuntan profesional dan terdaftar pada register negara sebagai akuntan. Mahasiswa yang dinyatakan lulus pendidikan program profesi akuntan berhak menggunakan gelar profesi dibidang akuntansi dan memperoleh sertifikat profesi akuntansi setelah mahasiswa dinyatakan lulus ujian sertifikasi akuntan profesional dan teregistrasi pada Register Negara (PerMenDikBud, 2014).

Akuntan adalah seseorang yang telah terdaftar pada Register Negara Akuntan yang diselenggarakan oleh Menteri Keuangan (PerMenKeu, 2014). Register Negara sebagai Akuntan adalah suatu daftar yang memuat nomor dan nama orang yang berhak menyandang gelar Akuntan sesuai dengan peraturan menteri keuangan nomor 25/PMK.01/2014 (PerMenKeu, 2014). Seorang akuntan profesional harus memegang teguh prinsipprinsip dasar: integritas, objektif, memiliki kompetensi profesional dibidangnya, dan berperilaku professional (IFAC, 2006).

Ujian sertifikasi akuntan profesional menjadi sarana bagi sarjana yang tertarik menjadi seorang akuntan terregister di Indonesia. Gelar profesi menjadi nilai tambah bagi seorang sarjana akuntansi untuk menunjukkan bahwa mereka juga seorang profesional dibidangnya. Jumlah profesi akuntan telah meningkat signifikan setiap tahunnya. Seperti digambarkan pada tabel berikut:

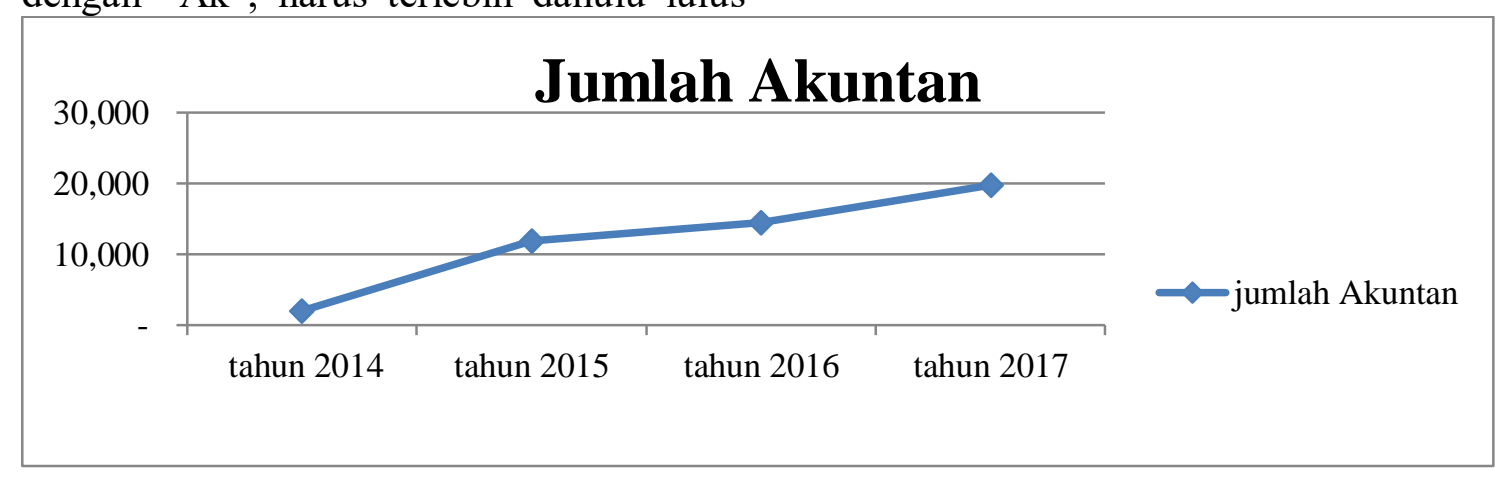

Sumber: Kementerian Keuangan, 2018. 


\section{Gambar 1}

\section{Jumlah Akuntan di Indonesia}

Berdasarkan pada tabel, jumlah akuntan terus mengalami peningkatan hingga saat ini. Hal ini menjadi perhatian bahwa banyak sarjana akuntansi sekarang mulai melirik ke profesi untuk meningkatkan karir dan menjadi profesional dibidangnya. Banyak sarjana sekarang termotivasi untuk melanjutkan studi ke profesi karena dinilai semiliki nilai tambah pada saat mencari kerja nantinya.

Peningkatan yang terjadi ini dipengaruhi oleh berbagai faktor, penelitian ini dilakukan untuk melihat motivasi dan persepsi terhadap minat mahasiswa Pendidikan Profesi Akuntansi (PPAk) dalam menempuh pendidikan hingga selesai. Ada hubungan atau keterkaitan antara motivasi, persepsi dan minat. Motivasi merupakan keinginan besar yang menjadi penggerak seseorang atau kelompok untuk mencapai suatu tujuan yang diharapkan. Motivasi memerlukan proses yang bertahap hingga keinginan itu dapat tercapai dengan maksimal. Motivasi diartikan juga sebagai faktor internal dan eksternal yang merangsang hasrat dan energi seseorang yang tertarik dan berkomitmen pada suatu pekerjaan, peran, subyek, atau terus menerus melakukan upaya untuk mencapai tujuan (Businessdictionary, 2015). Berdasarkan penjelasan tersebut, motivasi adalah sumber kekuatan baik berasal faktor internal maupun eksternal yang menjadi pendorong seseorang dalam melakukan aktivitas. Penelitian ini menggunakan motivasi sebagai variabel yang diteliti, motivasi yang digunakan adalah motivasi kualitas, motivasi karir, motivasi ekonomi dan motivasi sosial.

Persepsi merupakan proses kognitif yang dipergunakan seseorang untuk menafsirkan dan memahami dunia sekitarnya (Denziana dan Resti, 2017). Persepsi merupakan serangkaian proses membeda-bedakan serta memfokuskan perhatian pada suatu objek yang diperoleh dari informasi indrawi. Penelitian ini menggunkaan dua indikator variabel dalam mengukur persepsi. Variabel tersebut adalah persepsi biaya pendidikan dan persepsi lama studi.

Minat merupakan keinginan yang tinggi terhadap sesuatu. Minat merupakan salah satu aspek psikis manusia yang dapat mendorong untuk mencapai tujuan. Seseorang yang memiliki minat terhadap suatu objek, cenderung untuk memberikan perhatian atau merasa senang yang lebih besar kepada objek tersebet. Minat dapat menjadi sebab kegiatan dan sebab partisipasi dalam kegiatan itu. Demikian minat merupakan sesuatu yang dapat mendorong seseorang melakukan aktivitas tertentu untuk mencapai tujuan (Ilmihah, Jaliha dan Syafrizal, 2017).

Penelitian yang berhubungan dengan motivasi, persepsi dan minat telah banyak dilakukan. Penelitian ini merupakan replikasi dari penelitian terdahulu yang telah dilakukan. Melihat jumlah akuntan yang terus meningkat signifikan setiap tahunnya ini menarik peneliti untuk melakukan penelitian lebih lanjut terkait faktor yang mempengaruhi mahasiswa dalam memilih Pendidikan Profesi Akuntansi (PPAk). Penelitian sebelumnya telah dilakukan oleh Umar, Ibrahim (2014) yang menjelaskan bahwa minat pribadi merupakan faktor utama karir mahasiswa bidang akuntansi. Namun, Rababah, (2016) menerangkan bahwa tidak ada pengaruh minat pribadi terhadap pilihan mahasiswa dibidang akuntansi. Perbedaan penelitian ini menggambarkan bahwa terdapat banyak sekali faktor yang mempengaruhi minat, karir, dan pilihan mahasiswa dibidang akuntansi.

Penelitian lainnya juga dilakukan oleh Husin, Salman (2015) bahwa motivasi kualitas dan motivasi ekonomi mempunyai pengaruh signifikan terhadap minat mahasiswa akuntansi untuk mengikuti Pendidikan Profesi Akuntansi (PPAk). Panggabean dan Nana (2011) juga menyimpulkan bahwa motivasi kualitas 
dan motivasi karir berpengaruh positif terhadap minat mahasiswa mengikuti PPAk. Indrawati, Novita (2009) juga menyimpulkan bahwa motivasi kualitas, motivasi karir, dan motivasi sosial menunjukkan adanya pengaruh signifikan terhadap minat mahasiswa akuntansi untuk mengikuti PPAk. Sedangkan motivasi ekonomi tidak menunjukkan pengaruh yang signifikan terhadap minat mahasiswa dalam mengikuti PPAk.

Penelitian lainnya dilakukan oleh Denziana dan Rita (2017) tentang pengaruh motivasi, persepsi biaya pendidikan, persepsi lama pendidikan terhadap minat mahasiswa untuk mengikuti Pendidikan Profesi Akuntansi (PPAk) pada perguruan tinggi di Bandar Lampung. Hasil penelitian menunjukkan bahwa motivasi, pesepsi biaya pendidikan, persepsi lama pendidikan secara signifikan mempengaruhi minat mahasiswa untuk mengikuti Pendidikan Profesi Akuntansi (PPAk) pada perguruan tinggi di Bandar Lampung. Ilmiha dan Syafrizal (2017) juga menambahkan bahwa motivasi karir berpengaruh signifikan terhadap minat mahasiswa mengikuti Pendidikan Profesi Akuntansi (PPAk) dan Charterred accountant (CA), sedangkan motivasi kualitas dan ekonomi tidak berpengaruh signifikan.

Banyaknya penelitian yang telah dilakukan, memiliki hasil yang bervariasi. Perbedaan penelitian yang dilakukan terletak pada variabel yang digunakan, penelitian ini menggunakan variabel yang lebih banyak dan kompleks. Variabel yang diteliti merupakan gabungan dari variabel penelitian terdahulu. Berdasarkan pada studi empirik yang telah dipaparkan, menarik untuk dilakukan penelitian lebih lanjut dalam menganalisis pengaruh motivasi, persepsi terhadap minat mahasiswa dalam mengikuti PPAk. Penelitian ini bertujuan untuk menganalisis pengaruh motivasi (kualitas, karir, ekonomi, dan sosial) dan persepsi (biaya pendidikan, dan lama pendidikan) terhadap minat mahasiswa mengikuti PPAk di Kota
Semarang. Penelitian ini diharapkan dapat menggambarkan faktor yang menjadi minat mahasiswa untuk mengikuti PPAk di Kota Semarang, sehingga dapat diketahui dengan jelas peningkatan jumlah mahasiswa PPAk setiap tahunnya, khususnya di Kota Semarang.

\section{TINJAUAN PUSTAKA Motivasi}

Motivasi adalah kekuatan yang mendorong atau menggerakkan individu untuk mencapai tujuannya (Gibson, et al. 1996). Motivasi yang timbul dari dalam diri mahasiswa terdiri dari tiga hal, yaitu motivasi kualitas, motivasi karir dan motivasi ekonomi. Motivasi kualitas merupakan suatu dorongan yang timbul dalam diri seseorang untuk memiliki dan meningkatkan kualitas diri dan kemampuannya dalam bidang yang ditekuninya sehingga dapat melaksanakan tugas dengan baik dan benar. Motivasi karir adalah dorongan yang timbul dalam diri seseorang untuk meningkatkan kemampuan pribadinya dalam rangka mencapai kedudukan, jabatan atau karir yang lebih baik dari sebelumnya. Motivasi ekonomi adalah suatu dorongan yang timbul dalam diri seseorang untuk meningkatkan kemampuan pribadinya dalam rangka untuk mencapai penghargaan finansial yang diinginkan (Widyastuti dkk, 2004).

Selain jenis motivasi yang telah disebutkan tersebut, terdapat motivasi lain yang juga dimasukkan sebagai indikator motivasi, yaitu motivasi sosial. Buss et al. (1997) menyatakan bahwa pentingnya status sebagai motivasi sosial akan sangat berpengaruh terhadap tingkat kecemasan yang dialami seseorang, disamping itu motivasi sosial secara psikologis mampu mengabaikan peran dari jenis kelamin seseorang. Motivasi sosial merupakan aktivitas dasar yang pakai individu untuk melihat reaksinya terhadap orang lain, reaksi tersebut bisa berupa akibat dari aktivitas yang dilakukan bagi orang lain dinilai baik atau buruk (Martameh, 2012). 


\section{Persepsi}

Persepsi adalah proses diseleksi, diorganisir, dan diinterpretasikan untuk mempunyai gambaran tersendiri terhadap produk yang berbeda dengan orang lain. Motif seseorang untuk berperilaku seringkali didasarkan dari persepsi yang mereka rasakan, bukan berdasarkan fakta atau realitas yang mereka lihat. Persepsi dinilai sebagai pendapat individu tentang suatu masalah, tanpa dipandang baik atau tidaknya karena melihat pada sudut pandang yang berbeda (Setiadi, 2003). Persepsi yang erat kaitannya dengan pilihan melanjutkan studi adalah masalah biaya dan lamanya studi.

Menurut Peraturan Pemerintah Republik Indonesia No: 48/2008 yang termasuk dalam biaya pendidikan meliputi biaya administrasi/registrasi, biaya penyelenggaraan atau pengelolaan pendidikan, dan biaya pribadi peserta didik. Hidayat (2013) menjelaskan bahwa lama pendidikan adalah masa studi terjadwal yang harus ditempuh oleh mahasiswa sesuai dengan rentang waktu yang dipersyaratkan. Batas lama pendidikan adalah batas waktu maksimal yang diperkenankan untuk mahasiswa menyelesaikan studi yang meliputi batas waktu maksimal dalam menempuh pendidikan, dan tingkat kesulitan dalam kelulusan.

\section{Minat}

Minat

merupakan

suatu

kecenderungan yang menyebabkan seseorang berusaha untuk mencari ataupun mencoba aktivitas-aktivitas dalam bidang tertentu. Minat juga diartikan sebagai sikap positif terhadap aspek-aspek lingkungan (Sanjaya, 2006). Selain itu, minat juga merupakan kecenderungan yang tetap untuk memperhatikan dan menikmati suatu aktivitas disertai dengan rasa senang. Minat berkaitan dengan perasaan suka atau senang dari seseorang terhadap sesuatu objek. Minat sebagai suatu rasa lebih suka dan rasa keterikatan pada suatu hal atau aktivitas, tanpa ada yang menyuruh (Slameto, 2003). Minat untuk melanjutkan studi adalah minat dalam menyediakan waktu, tenaga, usaha untuk menyerap dan menyatukan informasi, pengetahuan, dan kecakapan yang kita terima lewat berbagai cara (Denziana dan Resti, 2017).

\section{Kerangka Pemikiran}

Kerangka penelitian yang digunakan dalam penelitian ini adalah:

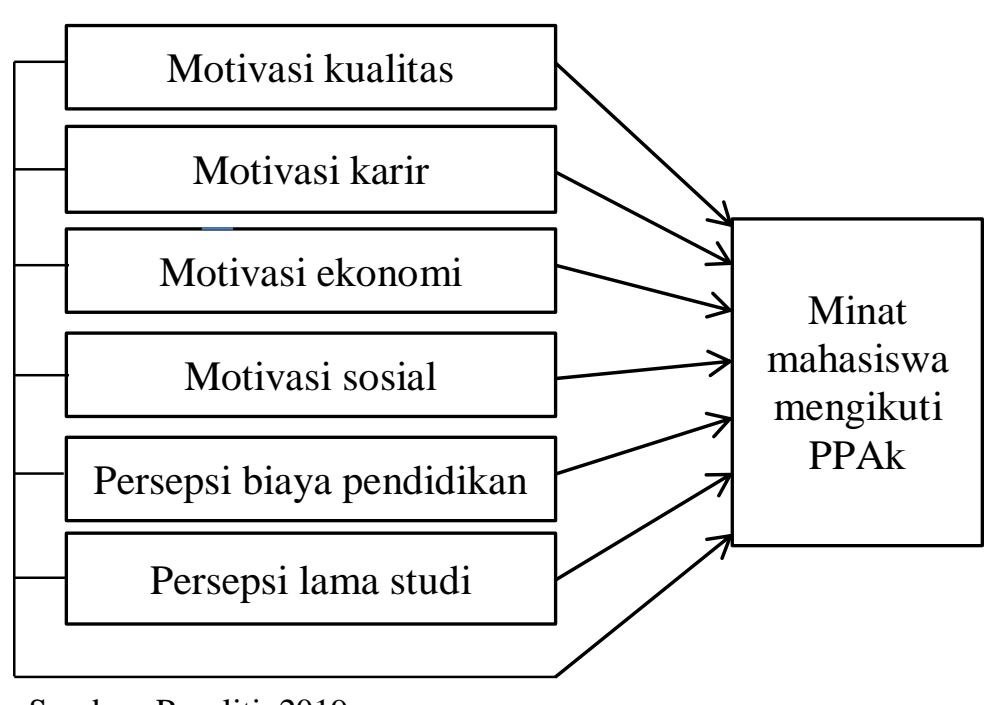

Sumber: Peneliti, 2019.

\section{Gambar 2 Kerangka Penelitian}

\section{Hipotesis Penelitian}

Hipotesis penelitiaan yang digunakan adalah:

H1 : Motivasi kualitas berpengaruh terhadap minat mahasiswa untuk mengikuti Pendidikan Profesi Akuntansi (PPAk).

H2 : Motivasi karir berpengaruh terhadap minat mahasiswa untuk mengikuti Pendidikan Profesi Akuntansi (PPAk).

H3 : Motivasi ekonomi berpengaruh terhadap minat mahasiswa untuk mengikuti Pendidikan Profesi Akuntansi (PPAk).

H4 : Motivasi sosial berpengaruh terhadap minat mahasiswa untuk 
mengikuti Pendidikan Profesi Akuntansi (PPAk).

H5 : Persepsi biaya pendidikan berpengaruh terhadap minat mahasiswa untuk mengikuti Pendidikan Profesi Akuntansi (PPAk).

H6 : Persepsi lama studi berpengaruh terhadap minat mahasiswa untuk mengikuti Pendidikan Profesi Akuntansi (PPAk).

\section{METODOLOGI PENELITIAN \\ Rancangan Penelitian}

Klasifikasi desain penelitian ini berupa penelitian deskriptif kuantitatif yang menjelaskan fenomena empiris yang disertai data statistik, karakteristik dan pola hubungan antar variabel. Penelitian ini menggunakan metode survei sebagai cara untuk mengumpulkan data. Survei dilakukan dengan memberikan angket yang berisi pernyataan-pernyataan kepada responden yaitu mahasiswa Pendidikan Profesi Akuntansi (PPAk) yang ada di Kota Semarang. Metode pengukuran dalam penelitian ini menggunakan skala likert dengan empat skala (1-4) yang digunakan untuk mengetahui penilaian seseorang terhadap suatu hal.

Kuesioner yang diajukan terdiri dari: 1) Karakteristik responden, meliputi: jenis kelamin, usia, pekerjaan orang tua, pendapatan orang tua, Latar Belakang Pendidikan dan tahun angkatan mahasiswa. 2) Kuesioner yang berkaitan dengan variabel yang diteliti, yaitu motivasi kualitas, motivasi karir, motivasi ekonomi, motivasi sosial, persepsi biaya pendidikan dan persepsi lama studi.

Objek penelitian adalah motivasi, persepsi dan minat mahasiswa mengikuti PPAk. Variabel penelitian terdiri dari variabel dependen dan independen.Variabel dependen yaitu minat mahasiswa mengikuti pendidikan PPAk. Variabel independen adalah motivasi kualitas, motivasi karir, motivasi ekonomi, motivasi sosial, persepsi biaya pendidikan dan persepsi lama studi.

Populasi dalam penelitian ini adalah semua mahasiswa PPAk yang ada di kota Semarang. Populasi yang ada dalam penelitian ini digunakan semua sebagai sampel. Hal ini dilakukan karena jumlah populasinya yang masih dalam jumlah kecil.

Jumlah populasinya kurang dari 100 orang, maka jumlah sampelnya diambil secara keseluruhan, tetapi jika populasinya lebih besar dari 100 orang, maka bisa diambil $10-15 \%$ atau $20-25 \%$ dari jumlah populasinya (Arikunto, 2012). Penelitian ini memiliki populasi sebanyak 84 orang, sehingga jumlah populasi menjadi jumlah semua sampel atau disebut sampel jenuh (sensus). Populasi terdiri atas dua tempat penelitian, yaitu di PPAk Universitas Diponegoro dan PPAk Universitas STIKUBANK Semarang. Masing-masing populasi adalah 40 orang dan 48 orang.

\section{Variabel Penelitian dan Definisi Operasional Variabel}

penelitian:

Berikut merupakan definisi operasional masing-masing variabel yang digunakan dalam

Tabel 4. Variabel Penelitian dan Definisi Operasional Variabel

\begin{tabular}{|c|c|c|}
\hline Variabel & Definisi & Indikator \\
\hline Motivasi kualitas & $\begin{array}{l}\text { Motivasi Kualitas diri merupakan dorongan } \\
\text { yang timbul dari dalam diri seseorang untuk } \\
\text { memiliki dan meningkatkan kualitas dan } \\
\text { kemampuan diri dalam bidang yang } \\
\text { ditekuninya sehingga dapat melaksanakan } \\
\text { tugas dengan baik (Kusumastuti dan } \\
\text { Waluyo, 2016). }\end{array}$ & $\begin{array}{l}\text { 1. } \begin{array}{l}\text { Memberikan pengetahuan, } \\
\text { terkait dengan akuntansi dan } \\
\text { keuangan }\end{array} \\
\text { 2. } \begin{array}{l}\text { Meningkatkan kemampuan diri } \\
\text { dibidang keuangan dan akuntansi }\end{array}\end{array}$ \\
\hline
\end{tabular}




\begin{tabular}{|c|c|c|}
\hline Motivasi karir & $\begin{array}{l}\text { Karir adalah sebuah keahlian yang dimiliki } \\
\text { seseorang di bidang ilmu yang ditekuni } \\
\text { yang peniliannya berdasarkan pada } \\
\text { pengalaman kerja yang akan memberikan } \\
\text { kontribusi pada organisasi (Kusumastuti } \\
\text { dan Waluyo, 2016). }\end{array}$ & $\begin{array}{l}\text { 1. Memberikan kesempatan dan } \\
\text { perlakuan karir lebih baik } \\
\text { 2. Meningkatkan profesionalitas } \\
\text { terhadap profesi akuntansi }\end{array}$ \\
\hline Motivasi ekonomi & $\begin{array}{l}\text { Menurut Abidin dan Ervanto (2015) } \\
\text { Motivasi ekonomi adalah sebuah dorongan } \\
\text { yang timbul pada diri seseorang guna } \\
\text { meningkatkan kemampuan diri dalam } \\
\text { rangka mencapai penghargaan secara } \\
\text { finansial yang diinginkan }\end{array}$ & $\begin{array}{l}\text { 1. } \begin{array}{l}\text { Memberikan motivasi terkait } \\
\text { gaji, insentif, tunjangan, bonus, } \\
\text { dan program pensiun yang lebih }\end{array} \\
\text { baik } \\
\text { 2. Meningkatkan status ekonomi } \\
\text { pekerja }\end{array}$ \\
\hline Motivasi sosial & $\begin{array}{l}\text { Motivasi sosial merupakan motivasi yang } \\
\text { mendasari aktivitas yang dilakukan } \\
\text { seseorang dalam reaksinya pada suatu hal, } \\
\text { jika ia dalam membuat pilihan } \\
\text { memperhitungkan akibatnya bagi orang lain } \\
\text { (Dyastari dan Yadnyana, 2016). }\end{array}$ & $\begin{array}{l}\text { 1. Membrikan motivasi relasi } \\
\text { dengan rekan kerja lebih baik } \\
\text { 2. Meningkatkan kegiatan sosial di } \\
\text { tempat kerja } \\
\text { 3. Profesi akuntansi dipandang } \\
\text { memberikan nilai lebih } \\
\text { dibandingkan profesi lain }\end{array}$ \\
\hline $\begin{array}{l}\text { Persepsi biaya } \\
\text { pendidikan }\end{array}$ & $\begin{array}{l}\text { Persepsi biaya pendidikan merupakan } \\
\text { sebuah proses saat individu mengatur dan } \\
\text { menginterpretasikan kesan-kesan sensoris } \\
\text { mereka terhadap keseluruhan pengorbanan } \\
\text { finansial yang dikeluarkan baik oleh orang } \\
\text { tua mahasiswa atau mahasiswa tersebut } \\
\text { untuk keperluan selama menempuh } \\
\text { pendidikan dari awal sampai berakhirnya } \\
\text { pendidikan (Lisnasari, 2008) }\end{array}$ & $\begin{array}{l}\text { 1. Biaya administrasi/registrasi } \\
\text { 2. Biaya perkuliahan } \\
\text { 3. Pengeluaran yang berkenaan } \\
\text { pada saat penyelenggaraan } \\
\text { PPAk. }\end{array}$ \\
\hline $\begin{array}{l}\text { Persepsi masa } \\
\text { studi }\end{array}$ & $\begin{array}{l}\text { Persepsi masa studi merupakan sebuah } \\
\text { proses saat individu mengatur dan } \\
\text { menginterpretasikan kesan-kesan sensoris } \\
\text { mereka terhadap masa studi terjadwal yang } \\
\text { harus ditempuh oleh mahasiswa tersebut } \\
\text { sesuai dengan rentang waktu yang telah } \\
\text { dipersyaratkan, untuk menilai persepsi } \\
\text { masa studi, peneliti menggunakan } \\
\text { pertanyaan yang diperoleh dari penelitian } \\
\text { Riani Nurainah Lisnasari (2008). }\end{array}$ & $\begin{array}{l}\text { 1. Batas waktu maksimal dalam } \\
\text { menempuh PPAk } \\
\text { 2. Masa studi di PPAk panjang } \\
\text { 3. Tingkat kesulitan dalam } \\
\text { kelulusan PPAk. }\end{array}$ \\
\hline $\begin{array}{l}\text { Minat Mengikuti } \\
\text { Pendidikan } \\
\text { Profesi Akuntansi }\end{array}$ & $\begin{array}{l}\text { Minat merupakan kegairahan atau } \\
\text { kecenderungan hati terhadap sesuatu hal, } \\
\text { hal dalam pengertian ini berarti kegairahan } \\
\text { dan kecenderungan hati untuk mengikuti } \\
\text { Pendidikan Profesi Akuntansi (PPAk) } \\
\text { (Lisnasari, 2008) }\end{array}$ & 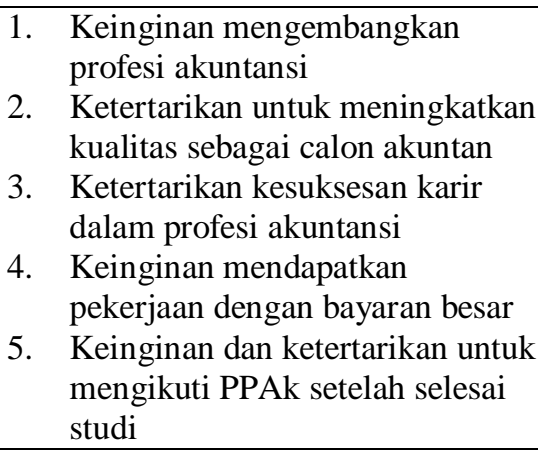 \\
\hline
\end{tabular}

Sumber: Data Diolah dari berbagai sumber (2020)

\section{Teknik Analisis Data}

Teknik analisis yang digunakan adalah analisis regresi linear berganda. Sebelum pengujian hipotesis dilakukan, terlebih dahulu dilakukan pengujian kualitas data dengan uji reliabilitas dan validitas serta uji asumsi klasik (meliputi uji normalitas, uji multikolonieritas dan uji heteroskedastisitas,). 
Uji validitas digunakan untuk mengukur sah atau valid tidaknya suatu kuesioner (Ghozali, 2016). Apabila dari tampilan output hasil analisis menunjukkan bahwa korelasi antara masing masing indikator terhadap total skor konstruk menunjukkan hasil yang signifikan, maka dapat disimpulkan bahwa masing-masing indikator pertanyaan adalah valid.

\section{Uji Reliabilitas}

Reliabilitas sebenarnya adalah alat untuk mengukur suatu kuesioner yang merupakan indikator dari variabel atau konstruk (Ghozali, 2016). Pengukuran reliabilitas dengan uji statistik Cronbach Alpha $(\alpha)$. Suatu konstruk atau variabel dikatakan reliabel jika memberikan nilai Cronbach Alpha > 0,60 (Ghozali, 2016).

\section{Uji Asumsi Klasik}

Sebelum dilakukan pengujian analisis regresi linier berganda terhadap hipotesis penelitian, maka terlebih dahulu perlu dilakukan suatu pengujian asumsi klasik atas data yang akan diolah sebagai berikut:

Uji Normalitas

Uji normalitas bertujuan untuk menguji apakah dalam model regresi, variabel pengganggu atau residual memiliki distribusi normal. Seperti diketahui bahwa uji $t$ dan $F$ mengasumsikan bahwa nilai residual mengikuti distribusi normal. Kalau asumsi ini dilanggar maka uji statistik menjadi tidak valid untuk jumlah sampel kecil. Ada dua cara untuk mendeteksi apakah residual berdistribusi normal atau tidak yaitu dengan analisis grafik dan uji statistik. Untuk menguji apakah data berdistribusi normal atau tidak dilakukan uji statistik Kolmogorov-Smirnov Test. Residual berdistribusi normal jika memiliki nilai signifikansi > 0,05 (Ghozali, 2016)

Uji Multikolonieritas

Menurut Ghozali (2016), uji multikolinieritas bertujuan untuk menguji apakah model regresi ditemukan adanya korelasi antar variabel bebas (independen).
Untuk menguji multikolinieritas dengan cara melihat nilai VIF masing-masing variabel independen. Jika nilai VIF $<10$, maka dapat disimpulkan data bebas dari gejala multikolinieritas.

Uji Heteroskedastisitas

Uji heterokedastisitas bertujuan menguji apakah dalam model regresi terjadi ketidaksamaan variance dari residual satu pengamatan ke pengamatan yang lain. Pengujian pada penelitian ini menggunakan Grafik Plot. heteroskedastisitas tidak terjadi apabila tidak ada pola yang jelas, serta titik-titik menyebar di atas dan di bawah angka 0 pada sumbu Y (Ghozali, 2016).

\section{Analisis Regresi Linear Berganda}

Penelitian ini menggambarkan suatu hubungan dimana satu atau lebih variabel (variabel independen) mempengaruhi variabel lainnya (variabel dependen). Oleh karena itu peneliti menggunakan analisis regresi linear berganda untuk menguji hipotesis dalam penelitian ini. Pengujian tersebut didasarkan pada persamaan regresi linear berganda sebagai berikut:

$$
\begin{aligned}
& \mathrm{Y}=\mathrm{a}+\mathrm{b} 1 \mathrm{X} 1+\mathrm{b} 2 \mathrm{X} 2+\mathrm{b} 3 \mathrm{X} 3+\mathrm{b} 4 \mathrm{X} 4+ \\
& \mathrm{b} 5 \mathrm{X} 5+\mathrm{b} 6 \mathrm{X} 6+\mathrm{e}
\end{aligned}
$$

\section{Keterangan:}

$$
\begin{aligned}
& \mathrm{Y}=\text { Tingkat Penerapan Standar } \\
& \text { Akuntansi Pemerintah Berbasis } \\
& \text { Akrual } \\
& \mathrm{X} 1=\text { Pelatihan } \\
& \mathrm{X} 2=\text { Pendampingan Aparatur } \\
& \text { Pemerintah Daerah } \\
& \text { X3 = Komitmen Organisasi } \\
& \mathrm{a}=\text { Konstanta } \\
& \mathrm{bX}=\text { koefisien regresi } \\
& \mathrm{e} \quad=\text { kesalahan residual }
\end{aligned}
$$

\section{Pengujian Hipotesis \\ Uji Simultan (Uji F)}

Uji F pada dasarnya menunjukkan apakah semua variabel independen atau bebas yang dimasukkan dalam model mempunyai pengaruh secara bersama- 
sama terhadap variabel dependen/terikat. Pada pengujian ini juga menggunakan tingkat signifikansi sebesar 5\% atau 0,05.

Uji Parsial (uji t) Tujuan dari uji parsial adalah untuk mengetahui seberapa jauh pengaruh dari variabel independen $(\mathrm{X})$ terhadap variabel dependen (Y) secara parsial. Pengujian hipotesis akan dilakukan dengan menggunakan tingkat signifikansi sebesar $0,05 \quad(\alpha=5 \%)$ atau tingkat keyakinan sebesar 0,95 .

Koefisien Determinasi $\left(\mathrm{R}^{2}\right)$

Koefisien determinasi $\left(\mathrm{R}^{2}\right)$ pada intinya mengukur seberapa jauh kemampuan model dalam menerangkan variasi variabel dependen. Nilai koefisien determinasi adalah antara nol dan satu (Ghozali, 2016).

\section{HASIL PENELITIAN \\ Deskripsi Sampel Penelitian}

Penelitian menggunakan kuesioner yang disebarkan kepada semua mahasiswa PPAk diwilayah Kota Semarang. Kuesioner yang terkumpul berjumlah 74 kuesioner. Total semua mahasiswa PPAk yang ada di Kota Semarang adalah 87 orang. Jumlah tersebut terdiri dari dua PPAk yaitu PPAk di Universitas Diponegoro berjumlah 40 orang dan PPAk di Universitas STIKUBANK berjumlah 48 orang. Total semua mahasiswa merupakan populasi pada penelitian ini. Namun, semua populasi bukanlah sampel yang digunakan dalam penelitian ini. Penentuan sampel menggunakan metode purposive sampling. Penentuan kriteria sampel dalam analisis ini adalah:

\section{Deskripsi Responden}

Penelitian ini menggunakan data yang diperoleh dari penyebaran kuesioner pada PPAk yang ada di Universitas Diponegoro dan Universitas STIKUBANK Semarang. Responden yang mengisi kuesioner ini berasal dari berbagai latar belakang yang berbeda-beda. Gambaran responden sebanyak 73 orang ini di lihat dari empat demografi, yaitu: gender, usia, latar belakang pendidikan, dan pengalaman magang di KAP (Kantor Akuntan Publik).
Hasil analisis demografi responden adalah sebagai berikut:

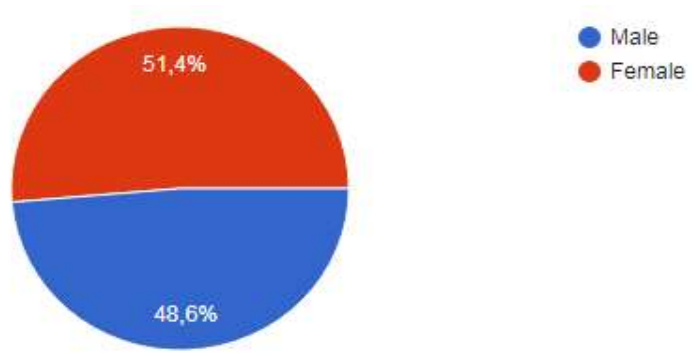

Gambar 3

Gender Responden

Sumber: Data diolah, 2019

Berdasarkan gambar 3 menjelaskan bahwa jumlah responden lebih banyak berjenis kelamin perempuan sebesar $51,4 \%$ dibandingkan laki-laki sebesar 48,6\%.

Klasifikasi responden berdasarkan usia adalah sebagai berikut:
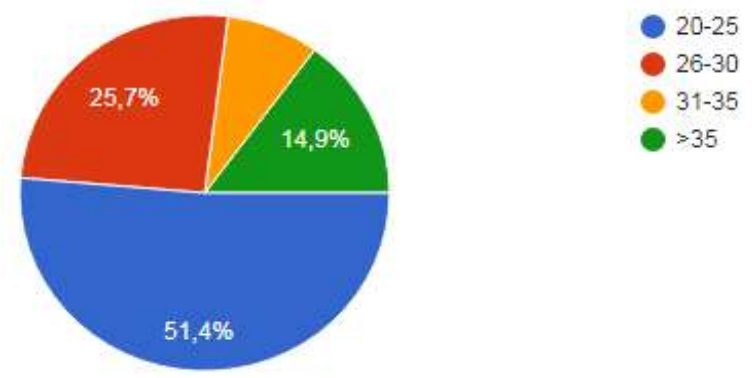

\section{Gambar 4}

Usia Responden

Sumber: Data diolah, 2019

Berdasarkan gambar 4 menjelaskan bahwa jumlah responden berdasarkan umur memiliki variasi yang berbeda-beda. Usia responden terbanyak adalah kisaran 20-25 tahun sebanyak 51,4\%, lalu usia 2630 tahun sebanyak $25,7 \%$, umur dengan jarak usia lebih dari 35 tahun sebanyak $14,9 \%$, dan usia 31-35 sebanyak $8,1 \%$.

Klasifikasi berdasarkan pada latar belakang pendidikan responden adalah sebagai berikut: 
dengan latar belakang pendidikan nonakuntansi.

Berikut merupakan klasifikasi responden berdasarkan pengalaman magang di KAP (Kantor Akuntan Publik) digambarkan sebagai berikut:

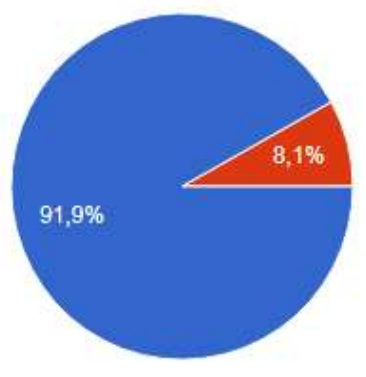

\section{Gambar 5}

Latar Belakang Pendidikan

Sumber: Data diolah, 2019

Berdasarkan gambar 5 menjelaskan bahwa jumlah responden berdasarkan pendidikan menunjukkan bahwa responden atau mahasiswa PPAk di Semarang lebih banyak berlatar belakang pendidikan akuntansi sebanyak 91,9\%. Sedangkan sisanya $8,1 \%$ merupakan responden

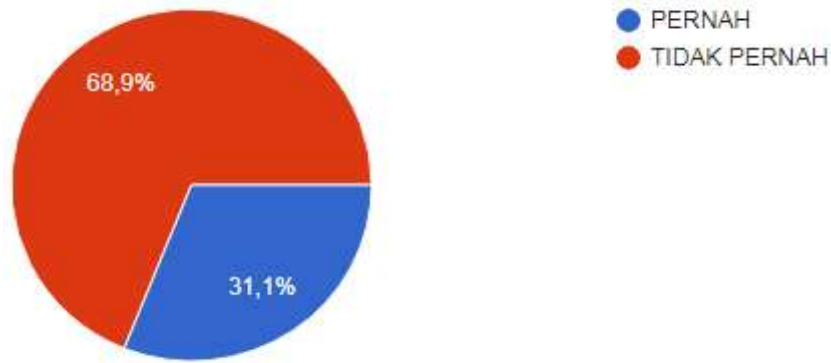

Gambar 6

Pengalaman Magang di KAP (Kantor Akuntan Publik)

Sumber: Data diolah, 2019

Berdasarkan gambar 6, jumlah responden berdasarkan pengalaman magang di KAP menunjukkan lebih banyak responden tidak pernah magang di KAP sebesar $68,9 \%$. Sedangkan sisanya $31,1 \%$ merupakan responden yang pernah magang di KAP.

\section{Uji Validitas}

Tabel 6

Hasil Pengujian Validitas - Product Moment

\begin{tabular}{|c|c|c|c|c|c|}
\hline Pertanyaan & T - Hitung & Keterangan & Pertanyaan & T - Hitung & Keterangan \\
\hline $\mathbf{X 1 . 1}$ & 0,382 & Valid & $\mathbf{X 4 . 2 6}$ & 0,560 & Valid \\
\hline $\mathbf{X 1 . 2}$ & 0,474 & Valid & $\mathbf{X 4 . 2 7}$ & 0,486 & Valid \\
\hline $\mathbf{X 1 . 3}$ & 0,262 & Valid & $\mathbf{X 4 . 2 8}$ & 0,500 & Valid \\
\hline $\mathbf{X 1 . 4}$ & 0,537 & Valid & $\mathbf{X 4 . 2 9}$ & 0,494 & Valid \\
\hline $\mathbf{X 1 . 5}$ & 0,366 & Valid & $\mathbf{X 4 . 3 0}$ & 0,437 & Valid \\
\hline $\mathbf{X 1 . 6}$ & 0,570 & Valid & $\mathbf{X 5 . 3 1}$ & 0,283 & Valid \\
\hline $\mathbf{X 1 . 7}$ & 0,512 & Valid & $\mathbf{X 5 . 3 2}$ & 0,319 & Valid \\
\hline $\mathbf{X 1 . 8}$ & 0,479 & Valid & $\mathbf{X 5 . 3 3}$ & 0,274 & Valid \\
\hline $\mathbf{X 2 . 9}$ & 0,645 & Valid & $\mathbf{X 5 . 3 4}$ & 0,411 & Valid \\
\hline $\mathbf{X 2 . 1 0}$ & 0,580 & Valid & $\mathbf{X 5 . 3 5}$ & 0,341 & Valid \\
\hline $\mathbf{X 2 . 1 1}$ & 0,646 & Valid & $\mathbf{X 5 . 3 6}$ & 0,262 & Valid \\
\hline $\mathbf{X 2 . 1 2}$ & 0,574 & Valid & $\mathbf{X 5 . 3 7}$ & 0,330 & Valid \\
\hline $\mathbf{X 2 . 1 3}$ & 0,602 & Valid & $\mathbf{X 5 . 3 8}$ & 0,312 & Valid \\
\hline
\end{tabular}




\begin{tabular}{|c|c|c|c|c|c|}
\hline Pertanyaan & T - Hitung & Keterangan & Pertanyaan & T - Hitung & Keterangan \\
\hline $\mathbf{X 2 . 1 4}$ & 0,617 & Valid & $\mathbf{X 6 . 3 9}$ & 0,292 & Valid \\
\hline $\mathbf{X 2 . 1 5}$ & 0,560 & Valid & $\mathbf{X 6 . 4 0}$ & 0,268 & Valid \\
\hline $\mathbf{X 2 . 1 6}$ & 0,540 & Valid & $\mathbf{X 6 . 4 1}$ & 0,370 & Valid \\
\hline $\mathbf{X 3 . 1 7}$ & 0,579 & Valid & $\mathbf{X 6 . 4 2}$ & 0,321 & Valid \\
\hline $\mathbf{X 3 . 1 8}$ & 0,589 & Valid & $\mathbf{X 6 . 4 3}$ & 0,264 & Valid \\
\hline $\mathbf{X 3 . 1 9}$ & 0,530 & Valid & $\mathbf{X 6 . 4 4}$ & 0,347 & Valid \\
\hline $\mathbf{X 3 . 2 0}$ & 0,680 & Valid & Y.45 & 0,323 & Valid \\
\hline $\mathbf{X 3 . 2 1}$ & 0,580 & Valid & $\mathbf{Y . 4 6}$ & 0,409 & Valid \\
\hline $\mathbf{X 3 . 2 2}$ & 0,519 & Valid & $\mathbf{Y . 4 7}$ & 0,420 & Valid \\
\hline $\mathbf{X 3 . 2 3}$ & 0,462 & Valid & $\mathbf{Y . 4 8}$ & 0,562 & Valid \\
\hline $\mathbf{X 3 . 2 4}$ & 0,650 & Valid & $\mathbf{Y . 4 9}$ & 0,358 & Valid \\
\hline $\mathbf{X 4 . 2 5}$ & 0,542 & Valid & $\mathbf{Y . 5 0}$ & 0,407 & Valid \\
\hline
\end{tabular}

Sumber : Data primer yang diolah, 2020

Pengujian ini menggunakan uji validitas dengan product moment berdasarkan jumlah peserta sebanyak 73 responden dan tingkat signifikasi sebesar $5 \%$, sehingga nilai t-tabel 0,2272 , artinya kuesioner adalah valid. Berdasarkan hasil analisis, menunjukkan bahwa semua pertanyaan pada kuesioner yang disebar telah valid dan atau memiliki ukuran yang tepat terhadap variabel yang digunakan. jika nilai yang pada t-hitung lebih besar dari nilai t-tabel, butir pertanyaan pada

\section{Uji Reliabilitas}

Hasil pengujian reliabilitas untuk masing-masing variabel yang diringkas pada tabel 4.4 berikut ini :

Tabel 7

\section{Hasil Pengujian Reliabilitas}

\begin{tabular}{|c|c|c|c|c|c|}
\hline Pertanyaan & $\begin{array}{c}\text { Cronbach's } \\
\text { alpha }\end{array}$ & Keterangan & Pertanyaan & T - Hitung & Keterangan \\
\hline $\mathbf{X 1 . 1}$ & & Reliabel & $\mathbf{X 4 . 2 6}$ & 0,560 & Valid \\
\hline $\mathbf{X 1 . 2}$ & 0,474 & Valid & $\mathbf{X 4 . 2 7}$ & 0,486 & Valid \\
\hline $\mathbf{X 1 . 3}$ & 0,262 & Valid & $\mathbf{X 4 . 2 8}$ & 0,500 & Valid \\
\hline $\mathbf{X 1 . 4}$ & 0,537 & Valid & $\mathbf{X 4 . 2 9}$ & 0,494 & Valid \\
\hline $\mathbf{X 1 . 5}$ & 0,366 & Valid & $\mathbf{X 4 . 3 0}$ & 0,437 & Valid \\
\hline $\mathbf{X 1 . 6}$ & 0,570 & Valid & $\mathbf{X 5 . 3 1}$ & 0,283 & Valid \\
\hline $\mathbf{X 1 . 7}$ & 0,512 & Valid & $\mathbf{X 5 . 3 2}$ & 0,319 & Valid \\
\hline $\mathbf{X 1 . 8}$ & 0,479 & Valid & $\mathbf{X 5 . 3 3}$ & 0,274 & Valid \\
\hline $\mathbf{X 2 . 9}$ & 0,645 & Valid & $\mathbf{X 5 . 3 4}$ & 0,411 & Valid \\
\hline $\mathbf{X 2 . 1 0}$ & 0,580 & Valid & $\mathbf{X 5 . 3 5}$ & 0,341 & Valid \\
\hline $\mathbf{X 2 . 1 1}$ & 0,646 & Valid & $\mathbf{X 5 . 3 6}$ & 0,262 & Valid \\
\hline $\mathbf{X 2 . 1 2}$ & 0,574 & Valid & $\mathbf{X 5 . 3 7}$ & 0,330 & Valid \\
\hline $\mathbf{X 2 . 1 3}$ & 0,602 & Valid & $\mathbf{X 5 . 3 8}$ & 0,312 & Valid \\
\hline $\mathbf{X 2 . 1 4}$ & 0,617 & Valid & $\mathbf{X 6 . 3 9}$ & 0,292 & Valid \\
\hline
\end{tabular}




\begin{tabular}{|c|c|c|c|c|c|}
\hline Pertanyaan & $\begin{array}{c}\text { Cronbach's } \\
\text { alpha }\end{array}$ & Keterangan & Pertanyaan & T - Hitung & Keterangan \\
\hline $\mathbf{X 2 . 1 5}$ & 0,560 & Valid & $\mathbf{X 6 . 4 0}$ & 0,268 & Valid \\
\hline $\mathbf{X 2 . 1 6}$ & 0,540 & Valid & $\mathbf{X 6 . 4 1}$ & 0,370 & Valid \\
\hline $\mathbf{X 3 . 1 7}$ & 0,579 & Valid & $\mathbf{X 6 . 4 2}$ & 0,321 & Valid \\
\hline $\mathbf{X 3 . 1 8}$ & 0,589 & Valid & $\mathbf{X 6 . 4 3}$ & 0,264 & Valid \\
\hline $\mathbf{X 3 . 1 9}$ & 0,530 & Valid & $\mathbf{X 6 . 4 4}$ & 0,347 & Valid \\
\hline $\mathbf{X 3 . 2 0}$ & 0,680 & Valid & $\mathbf{Y . 4 5}$ & 0,323 & Valid \\
\hline $\mathbf{X 3 . 2 1}$ & 0,580 & Valid & $\mathbf{Y . 4 6}$ & 0,409 & Valid \\
\hline $\mathbf{X 3 . 2 2}$ & 0,519 & Valid & $\mathbf{Y . 4 7}$ & 0,420 & Valid \\
\hline $\mathbf{X 3 . 2 3}$ & 0,462 & Valid & $\mathbf{Y . 4 8}$ & 0,562 & Valid \\
\hline $\mathbf{X 3 . 2 4}$ & 0,650 & Valid & $\mathbf{Y . 4 9}$ & 0,358 & Valid \\
\hline $\mathbf{X 4 . 2 5}$ & 0,542 & Valid & $\mathbf{Y . 5 0}$ & 0,407 & Valid \\
\hline
\end{tabular}

Sumber : Data primer yang diolah, 2020

Pengujian

multikolinearitas dilakukan dengan menggunakan nilai VIF dan tolerance. Pengujian multikolinieritas dijelaskan pada Tabel 9 berikut :

pengujian reliabilitas dari masing-masing pengukuran variabel diperoleh bahwa semua variabel mempunyai koefisien Alpha yang lebih besar dari 0,60 sehingga dapat dikatakan semua konsep pengukur variabel-variabel yang digunakan dalam penelitian ini adalah reliabel.

\section{Uji Asumsi Klasik}

\section{Uji Normalitas}

Pengujian asumsi normalitas dilakukan dengan menggunakan Uji Kolmogorov Smirnov terhadap nilai residual model regresi. Hasil pengujian normalitas dapat dilihat pada Tabel 8 berikut ini :

Tabel 8

\section{Uji Normalitas}

\begin{tabular}{|l|c|c|}
\hline \multicolumn{3}{|c|}{ One-Sample Kolmogorov-Smirnov Test } \\
\hline Statistic & df & Sig. \\
\hline $\mathbf{0 , 0 8 3}$ & 73 & 0,200 \\
\hline
\end{tabular}

Sumber : Data primer yang diolah, 2020

Berdasarkan tabel 8. di atas, hasil pengujian tersebut menunjukkan nilai signifkansi Kolmogorov Smirnov juga menunjukkan sebesar 0,200 yang lebih besar dari 0,05. Hal ini membuktikan bahwa variabel yang diteliti distribusi normal.

\section{Uji Multikolinearitas}

Tabel 9

Hasil Pengujian Multikolinieritas

\begin{tabular}{lcc}
\hline \multirow{2}{*}{ Variabel } & \multicolumn{2}{c}{ Uji multikolinieritas } \\
\cline { 2 - 3 } & Tolerance & VIF \\
\hline X1: Motivasi Kualitas & .552 & 1.812 \\
\hline X2: Motivasi Karir & .447 & 1.237 \\
\hline X3:Motivasi Ekonomi & .588 & 1.700 \\
\hline X4: Motivasi Sosial & .545 & 1.834 \\
\hline $\begin{array}{l}\text { X5: Persepsi Biaya } \\
\text { Pendidikan }\end{array}$ & .604 & 1.656 \\
\hline $\begin{array}{l}\text { X6: Persepsi Lama } \\
\text { Studi }\end{array}$ & .610 & 1.639 \\
\hline
\end{tabular}

Variabel Dependen:

Minat Mahasiswa

Sumber : Data primer yang diolah, 2020

Dari hasil tersebut menunjukkan bahwa variabel bebas tidak mempunyai nilai VIF yang berada dibawah angka 10 dan nilai tolerance diatas 0,1 sehingga dapat dikatakan semua konsep pengukur variabel-variabel yang digunakan tidak mengandung masalah multikolinieritas. Untuk itu variabel-variabel tersebut adalah saling independen.

\section{Uji Heteroskedastisitas}

Pengujian heteroskedastisitas dilakukan dengan menggunakan uji Glejser. Jika tidak terdapat hasil yang 
signifikan, maka disimpulkan bahwa model regresi tidak mengandung adanya gejala heteroskedastisitas. Hasil pengujian Heteroskedastisitas dipaparkan dalam Tabel 10 berikut :
7,627 dengan signifikansi sebesar 0,000. Nilai signifikansi pengujian tersebut lebih kecil dari taraf signifikansi 0,05. Dengan demikian maka ditunjukkan bahwa pada taraf signifikansi 5\%, model pengujian menunjukkan semua variabel independen terbukti secara Simultan berpengaruh terhadap minat mahasiswa mengikuti PPAk.

\section{Koefisien Determinasi}

Besarnya pengaruh dari ketiga variabel bebas terhadap variable terikatnya yaitu penerapan standar akuntansi pemerintah berbasis akrual ditunjukkan dengan nilai koefisien determinasi. Berdasarkan tabel 4.12 di atas, nilai Adjusted $R^{2}$ dari model regresi diperoleh sebesar 0,356, yang berarti bahwa 35,6\% minat mahasiswa mengikuti PPAk dapat dijelaskan oleh ke-6 variabel bebas yaitu Motivasi kualitas, motivasi karir, motivasi sosial, persepsi biaya dan persepsi lama studi. Sedangkan sisanya $64,4 \%$ minat mahasiswa mengikuti PPAk dapat dipengaruhi oleh variabel lain.

\section{Pengujian Hipotesis}

Hasil pengujian hipotesis penelitian dengan menggunakan bantuan program SPSS dengan menggunakan Uji Regresi Linier dideskripsikan di dalam Tabel 4.14 di bawah ini :

Tabel 12

\section{Model Regresi Linier}

\begin{tabular}{|c|c|c|c|c|c|c|}
\hline & & $\begin{array}{l}\text { Unstan } \\
\text { d Coef }\end{array}$ & $\begin{array}{l}\text { dardize } \\
\text { icients }\end{array}$ & $\begin{array}{l}\text { Standardized } \\
\text { Coefficients }\end{array}$ & & \\
\hline & & B & $\begin{array}{l}\text { Std. } \\
\text { Error }\end{array}$ & Beta & $\mathrm{t}$ & Sig. \\
\hline 1 & (Constant) & 6.412 & 2.593 & & 2.473 & .016 \\
\hline & X1: Motivasi Kualitas & .063 & .104 & .077 & .604 & .548 \\
\hline & X2: Motivasi Karir & .357 & .098 & .521 & 3.635 & .001 \\
\hline & X3:Motivasi Ekonomi & -.118 & .067 & -.224 & -1.794 & .077 \\
\hline & X4: Motivasi Sosial & .258 & .121 & .273 & 2.126 & .037 \\
\hline & $\begin{array}{l}\text { X5: Persepsi Biaya } \\
\text { Pendidikan }\end{array}$ & -.001 & .086 & -.002 & -.015 & .988 \\
\hline & X6: Persepsi Lama Studi & -.018 & .125 & -.017 & .142 & .888 \\
\hline
\end{tabular}

Sumber : Data primer yang diolah, 2020

Sesuai dengan Tabel 12 di atas, yang menjelaskan hasil uji hipotesis dalam

\section{Tabel 11}

\section{Uji Simultan}

\begin{tabular}{lc}
\hline \multicolumn{1}{c}{ Ukuran Statistik } & Nilai \\
\hline $\mathbf{F}$ & 7,627 \\
\hline Sig $\mathbf{~}$ & 0,000 \\
\hline $\mathbf{R}^{\mathbf{2}}$ & 0,409 \\
\hline Adj. $\mathbf{R}^{\mathbf{2}}$ & 0,356 \\
\hline \multicolumn{2}{c}{ Sumber : Data primer yang diolah, 2017}
\end{tabular}

Hasil pengujian model secara keseluruhan menunjukkan nilai $\mathrm{F}$ sebesar 
penelitian ini dengan mempertimbangkan nilai $\mathrm{t}$ dan signifikansinya pada tingkat siginifikansi $\alpha=0,05$. Hipotesis akan terdukung apabila nilai siginifikansinya lebih kecil dari nilai $\alpha=0,05$. Berikut ini penjabaran hasil Hipotesis 1 sampai dengan Hipotesis 6 sebagai berikut :

\section{Motivasi kualitas berpengaruh terhadap minat mahasiswa mengikuti PPAk di Semarang}

Hasil pengujian pengaruh motivasi kualitas terhadap minat mahasiswa mengikuti ppak di semarang menunjukkan nilai $\mathrm{t}$ sebesar 0.604 dan signifikansi sebesar 0,548. Nilai signifikansi pengujian tersebut lebih besar dari taraf signifikansi $\alpha$ $=0,05$. Dengan demikian maka ditunjukkan bahwa Motivasi kualitas tidak berpengaruh terhadap minat mahasiswa mengikuti PPAk di Semarang. Hal ini berarti Hipotesis 1 ditolak

\section{Motivasi karir berpengaruh terhadap minat mahasiswa mengikuti PPAk di Semarang}

Variabel motivasi karir berpengaruh terhadap minat mahasiswa mengikuti ppak di semarang memiliki koefisien dengan arah positif. Hasil pengujian pengaruh motivasi karir terhadap minat mahasiswa mengikuti ppak di semarang menunjukkan nilai $\mathrm{t}$ sebesar 3.635 dan signifikansi sebesar 0,001. Nilai signifikansi pengujian tersebut lebih kecil dari taraf signifikansi $\alpha=0,05$. Dengan demikian maka ditunjukkan bahwa pada $\alpha$ $5 \%$, motivasi karir berpengaruh terhadap minat mahasiswa mengikuti ppak di semarang. Hal ini berarti Hipotesis 2 diterima.

\section{Motivasi ekonomi berpengaruh} terhadap minat mahasiswa mengikuti PPAk di Semarang

Hasil pengujian variabel motivasi ekonomi berpengaruh terhadap minat mahasiswa mengikuti ppak di semarang menunjukkan nilai t sebesar 1.794 dan signifikansi sebesar 0,77. Nilai signifikansi pengujian tersebut lebih besar dari taraf signifikansi $\alpha=0,05$. Dengan demikian maka motivasi ekonomi tidak berpengaruh terhadap minat mahasiswa mengikuti ppak di semarang hal ini berarti hipotesis 1 ditolak.

\section{motivasi sosial berpengaruh terhadap minat mahasiswa mengikuti PPAk di Semarang}

Arah koefisien regresi variabel motivasi sosial berpengaruh terhadap minat mahasiswa mengikuti ppak di semarang diperoleh dengan arah positif. Hasil pengujian menunjukkan nilai $t$ sebesar 2.126 dan signifikansi sebesar 0,37 . Nilai signifikansi pengujian tersebut lebih kecil dari taraf signifikansi $\alpha=0,05$. Dengan demikian maka pada $\alpha 5 \%$, motivasi sosial berpengaruh terhadap minat mahasiswa mengikuti ppak di semarang Hal ini berarti Hipotesis 1 diterima.

\section{Persepsi biaya pendidikan berpengaruh terhadap minat mahasiswa mengikuti PPAk di Semarang}

Hasil pengujian pengaruh persepsi biaya pendidikan berpengaruh terhadap minat mahasiswa mengikuti ppak di semarang menunjukkan nilai $\mathrm{t}$ sebesar 0.015 dan signifikansi sebesar 0,988 . Nilai signifikansi pengujian tersebut lebih besar dari taraf signifikansi $\alpha=0,05$. Dengan demikian maka ditunjukkan bahwa persepsi biaya pendidikan tidak berpengaruh terhadap minat mahasiswa mengikuti ppak di semarang. Hal ini berarti Hipotesis 1 ditolak.

Persepsi lama studi berpengaruh terhadap minat mahasiswa mengikuti PPAk di Semarang

Hasil pengujian pengaruh persepsi lama studi terhadap minat mahasiswa mengikuti ppak di semarang menunjukkan nilai $\mathrm{t}$ sebesar 0.142 dan signifikansi sebesar 0,888 . Nilai signifikansi pengujian 
tersebut lebih besar dari taraf signifikansi $\alpha$ $=0,05$. Dengan demikian maka ditunjukkan bahwa persepsi lama studi tidak berpengaruh terhadap minat mahasiswa mengikuti PPAk di Semarang. Hal ini berarti Hipotesis 1 ditolak.

\section{PEMBAHASAN}

Penelitian ini menunjukkan pengaruh motivasi dan persepsi terhadap minat mahasiswa mengikuti PPAk di Kota Semarang. Secara empiris hasil penelitian membuktikan bahwa motivasi (kualitas, karir, ekonomi dan sosial) dan persepsi (biaya pendidikan dan lama studi) secara simultan berpengaruh signifikan terhadap minat mahasiswa akuntansi mengikuti PPAk. Berdasarkan analisis parsial, motivasi karir dan motivasi sosial yang berpengaruh positif signifikan terhadap minat mahasiswa akuntansi melanjutkan studi PPAk di kota Semarang. Sedangkan variabel lainnya seperti motivasi kualitas, motivasi ekonomi, persepsi biaya pendidikan dan persepsi lama studi tidak berpengaruh terhadap minat mahasiswa akuntansi mengikuti PPAk di kota Semarang. Mahasiswa PPAk di Kota semarang telah memilih untuk melanjutkan studi ke profesi akuntansi karena adanya motivasi karir dan sosial.

Berdasarkan pada motivasi karir, keluaran dari PPAk bagi mahasiswa bisa menjadi nilai tambah pada saat mencari kerja. Selain itu, memberikan kesemptan dalam karir yang lebih baik dan menjadi profesional dibidang akuntansi. Sedangkan motivasi sosial berpengaruh positif terhadap minat karena dengan mengikuti PPAk, memberikan relasi lebih luas dan rekan kerja yang lebih baik. akuntansi dinilai memberikan nilai lebih dibandingkan dengan profesi lainnya.

\section{KESIMPULAN}

Berdasarkan hasil penelitian yang telah dilakukan menunjukkan bahwa secara simultan motivasi kualitas, motivasi karir, motivasi ekonomi motivasi sosial persepsi biaya pendidikan dan persepsi lama studi berpengaruh signifikan terhadap minat mahasiswa akuntansi mengikuti PPAk. Namun, berdasarkan analisis parsial, hanya motivasi karir dan motivasi sosial yang berpengaruh positif signifikan terhadap minat mahasiswa akuntansi melanjutkan studi PPAk di kota Semarang. Sedangkan variabel lainnya seperti motivasi kualitas, motivasi ekonomi, persepsi biaya pendidikan dan persepsi lama studi tidak mempengaruhi minat mahasiswa akuntansi mengikuti PPAk di kota Semarang.

Mahasiswa PPAk di Kota semarang melanjutkan studi ke PPAk karena alasan karir dan sosial. PPAk mampu memberikan gambaran karir yang lebih baik. Bagi mahasiswa, lulusan PPAk menjadi nilai tambah saat melamar pekerjaan yang diinginkan. Selain itu, mereka beranggapan bahwa lulusan PPAk memberikan kesempatan dalam karir yang lebih baik dan menjadi profesional dibidang akuntansi. Berdasarkan pada motivasi sosial, lulusan PPAk memberikan pengalaman, dan jaringan yang lebih luas dan rekan kerja yang lebih baik. PPAk dinilai memberikan nilai lebih dibandingkan dengan lulusan sarjana akuntansi.

Penelitian ini masih membutuhkan berbagai pembaharuan dengan menambahkan populasi dan sampel agar dapat digeneralisasi secara nasional. Penelitian mendatang untuk lebih memisahkan antara jumlah sampel berdasarkan gender dan dilakukan analisis lebih lanjut. Serta menambahkan jumlah responden dari perguruan tinggi tersebut namun berminat untuk mengikuti studi lebih lanjut di PPAk. Untuk akuntan pendidik di PPAk pada perguruan tinggi juga harus memberikan pemahaman lebih untuk mahasiswa agar semakin berminat untuk mengikuti PPAk di perguruan tinggi dengan semakin banyaknya juga persaingan dalam profesi yang ada. 


\section{DAFTAR PUSTAKA}

Abidin, A.Z. dan Adi Darmawan Ervanto. 2015. Pengaruh Motivasi Terhadap Minat Mahasiswa Akuntansi Mengikuti Ujian Certified Public Accountant (CPA). JAFFA. Vol.03, No.1.

Arikunto, Suharsimi. 2007. Prosedur penelitian suatu Pendekatan Praktik. Jakarta: Rineka Cipta.

Business Dictionary. 2018. Pengertian Motivasi.

www.businessdictionary.com/definiti on/motivation.html. Diakses pada 2 Desember 2018.

Buss, David, M. 1997. Human Social Motivation in Evolutionary Perspective: Grounding Terror Management Theory. Psychological Inquiry Vol. 8 No. 1.

Denziana, Angrita dan Resti F. Febriani. 2017. Pengaruh Motivasi, Persepsi Biaya Pendidikan dan Lama Pendidikan Terhadap Minat Mahasiswa Akuntansi untuk Mengikuti Pendidikan Profesi Akuntansi (PPAk) (Studi Kasus Pada Perguruan Tinggi di Bandar Lampung). SENARAI-Jurnal Akuntansi dan Keuangan. Vol. 8 No. 2. ISSN: 2087-2054

Djaali. 2008. Psikologi Pendidikan. Jakarta; Bumi Akasara.

Dyastari, N.I.S dan I Ketut Yadnyana. 2016. Pengaruh Minat Mahasiswa Non-Akuntansi untuk Mengikuti Pendidikan Profesi Akuntansi. Ejurnal Akuntansi Universitas Udayana.Vol.16.1.

Gibson, Ivancevich, Donelly. 1996. Organisasi, Perilaku, Struktur, Proses. Jakarta: Bina Rupa Aksara.

Hidayat, Syarif. 2013. Teori dan Prinsip Pendidikan. Tangerang: PT Pustaka Mandiri.
International Federation of Accountants (IFAC). 2006. Prinsip Dasar Akuntan Profesional. https://www.ifac.org/system/files/pu blications/files/ifac-code-of-ethicsfor.pdf. Diakses pada 30 November 2018.

Ilmiha, Jalila dan Syafrizal. 2017. Pengaruh Motivasi Kualitas, Motivasi Karir Dan Motivasi Ekonomi Terhadap Minat Mahasiswa Mengikuti Pendidikan Profesi. Jurnal Riset Akuntansi Multiparadigma (JRAM), Vol. 4. No. 3.

Indrawati, Novita. 2009. Motivasi dan Minat Mahasiswa untuk Mengikuti Pendidikan Profesi Akuntansi (PPAk). Pekbis Jurnal. Vol. 1 No. 2.

Kamus Besar Bahasa Indonesia Pusat Bahasa. 2008. Pengertian Motivasi. https://kbbi.web.id/motivasi. Diakses pada 2 Desember 2018.

Kementerian Keuangan. 2018. Jumlah Akuntan Pertahun. http://pppk.kemenkeu.go.id. Diakses pada 30 November 2018.

Keputusan Menteri Pendidikan Nasional Republik Indonesia Nomor 179/U/2001 Tentang Penyelenggaraan Pendidikan Profesi Akuntansi. Diakses 20 Desember 2018.

Kusumastuti, Rita dan Indarto Waluyo. 2013. Pengaruh Motivasi Dan Pengetahuan Undang-Undang No.5 Tahun 2011 Tentang Akuntan Publik Terhadap Minat Mahasiswa Akuntansi Mengikuti Pendidikan Profesi Akuntansi (PPAk). Jurnal Nominal. Vol.2, No 2.

Martameh, Mulyani Sri. 2012. Motivasi Sosial. Yogyakarta: Universitas Gajah Mada.

Panggabean, Rosinta Ria dan Nana W. Kusumaningsih. 2011. Pengaruh 
Motivasi Terhadap Minat Mahasiswa Akuntansi Universitas Bina Nusantara Angkatan 2006 Untuk Mengikuti Pendidikan Profesi Akuntansi Binus Business Review Vol. 2 No. 1 Hal: 160-172

Peraturan Menteri Keuangan Republik Indonesia Nomer 25/PMK.01/2014. Tentang akuntan beregister Negara.

Peraturan Menteri Pendidikan dan Kebudayaan Republik Indonesia Nomor 153 Tahun 2014. Tentang Penyelenggaraan Pendidikan Program Profesi Akuntan.

Peraturan Pemerintah Republik Indonesia Nomor 48. 2008 Tentang Pendanaan Pendidikan.

Rababah, abedalqader. 2016. Factors Influencing the Students' Choice of Accounting as a Major: The Case of $\mathrm{X}$ University in United Arab Emirates. International Business Research Vol. 9. No. 10. http://ibr.ccsenet.org

Riani Nurainah Linasari Fitriany. 2008. Faktor-Faktor Yang Mepengaruhi Minat Mahasiswa Akuntansi Untuk Mengikuti Pendidikan Profesi Akuntansi (PPAk) (Studi Empiris di Universitas Indonesia). The 2nd Accounting Conference, 1st Doctoral Colloquium, and Accounting Workshop: Depok.

Salman Husin. 2015. Pengaruh Motivasi Kualitas Dan Motivasi Ekonomi Terhadap Minat Mahasiswa Akuntansi Untuk Mengikuti Pendidikan Profesi Akuntansi (Ppak) Dengan Kepribadian Individu Sebagai Variabel Moderating (Studi Empiris pada Mahasiswa Akuntansi Fakultas Ekonomi Universitas Riau dan Universitas Andalas). Jom Fekon Vol. 2 No. 1.

Sanjaya, W. 2006. Strategi Pembelajaran. Jakarta: Kencana Prenada Media Group.
Sardiman. AM. 2014. Interaksi dan Motivasi Belajar Mengajar. Cetakan ke-22. Jakarta: Rajawali Pers.

Setiadi Nugroho J. (2003). Perilaku Konsumen: Konsep dan Implikasi untuk Strategi dan Penelitian Pemasaran. Jakarta: Prenada Media Grup.

Slameto. 2003. Belajar dan Faktor-Faktor yang Mempengaruhinya. Jakarta: Rineka Cipta.

Sugiyono. 2010. Metodologi Penelitian Kuantitatif. Jakarta: PT Salemba Empat

Umar, Ibrahim. 2014. Factors Influencing Students' Career Choice in Accounting: The Case of Yobe State University. Research Journal of Finance and Accounting Vol.5. No.17. ISSN 2222-1697 (Paper) ISSN 2222-2847 (Online) Www.iiste.org.

Widyastuti, S.W, Juliana, K dan Sri Suryaningsum. (2004). "Pengaruh Motivasi terhadap Minat Mahasiswa Akuntansi untuk Mengikuti Pendidikan Profesi Akuntansi (PPAk)". Simposium Nasional Akuntansi VII: Bali. 